\title{
Pengaruh Model Pembelajaran Berbasis Masalah Menggunakan Alat Sederhana Terhadap Pemahaman Konsep Zat Pada Siswa Kelas VIISMP Negeri 1 Sindue Tobata
}

\author{
Fajrian, Marungkil Pasaribu dan Nurjannah \\ e-mail: Fajrianiyan@yahoo.com \\ Program Studi Pendidikan Fisika FKIP Universitas Tadulako \\ Jl. Soekarno Hatta Km. 9 Kampus Bumi Tadulako Tondo Palu - Sulawesi Tengah
}

\begin{abstract}
Abstrak - Penelitian ini bertujuan untuk melihat pengaruh pemahaman konsep zat siswa yang diajarkan dengan menggunakan model problem based learning dan model konvensional, pada kelas VII di SMP Negeri 1 Sindue Tobata. Jenis penelitian yang digunakan adalah kuasi eksperimen dengan desain "The Non Equivalen Pretest-Posttest Design". sampel dipilih dengan menggunakan teknik purposive sampling dan menghasilkan kelas VII A sebagai kelas eksperimen dan kelas VII B sebagai kelas kontrol. Instrumen yang digunakan berupa tes pemahaman konsep dalam bentuk pilihan ganda dan esai. Berdasarkan hasil pengolahan data, diperoleh rerata skor pretest pemahaman konsep siswa kelas eksperimen adalah 6,57 dan untuk posttest adalah 12,27. Untuk kelas kontrol diperoleh rerata skor pretest 6,00 sedangkan untuk posttest adalah 7,00. Analisis data tes dilakukan dengan teknik statistik uji-t dua pihak untuk menguji perbedaan rerata skor pemahaman konsep siswa dengan signifikansi $\alpha=0,05$. Diperoleh nilai hasil thitung $=12,5$ dan tabel $=2,00$. Ini berarti bahwa nilai $t_{\text {hitung }}$ berada diluar daerah penerimaan Ho. Dengan demikian dapat disimpulkan bahwa, terdapat perbedaan pemahaman konsep antara kelas yang mendapatkan pembelajaran menggunakan model problem based learning dan pembelajaran menggunakan model konvensional.
\end{abstract}

Kata Kunci: Model Problem Based Learning, Alat Sederhana, Pemahaman Konsep

\section{PENDAHULUAN}

Fisika merupakan ilmu yang mempelajari gejala-gejala dan peristiwa alam, serta berusaha untuk mengungkap segala rahasia alam semesta. Fisika menjadi sangat penting seiring dengan perkembangan ilmu pengetahuan dan teknologi yang semakin maju. Sebagai salah satu ilmu dasar yang memiliki nilai esensial yang dapat diterapkan dalam berbagai bidang kehidupan. Dalam pembelajaran fisika yang berkualitas tidak lepas dari peran guru.

Guru dituntut mampu menciptakan situasi pembelajaran yang aktif, kreatif, inovatif, efektif dan menyenangkan dalam proses pembelajaran khususnya pembelajaran fisika.

Nurjannah [1] dalam hasil penelitiannya mengatakan bahwa Siswa mampu menghafal konsep-konsep dalam sains tetapi, ketika berhadapan dengan masalah di kehidupan sehari-hari yang memerlukan penerapan sains, siswa tidak mampu mengaplikasikannya untuk memecahkan masalah.

Salah satu penyebab hal ini adalah pemilihan model pembelajaran yang kurang tepat. Sehingga salah satu model pembelajaran yang sesuai untuk diterapkan dalam permasalahan ini adalah Model Pembelajaran berbasis masalah.

Model Pembelajaran Berbasis Masalah dapat meningkatkan hasil belajar siswa karena, model pembelajaran ini mencoba membuat proses berfikir siswa lebih baik.

Tan [2] dalam hasil penelitiannya menyimpulkan bahwa dibandingkan dengan model pembelajaran konvensional, lebih baik digunakan model pembelajaran berbasis masalah yang mampu mengkonstruksi konsep dan mengembangkan keterampilan proses.

Hal ini juga disebabkan oleh, berpusatnya proses pembelajaran pada guru, mengakibatkan pembelajaran fisika akhirnya agak membosankan dan menjadikan siswa cepat merasa jenuh sehingga tidak ada keterkaitan siswa untuk mempelajarinya. Selama ini pembelajaran fisika lebih didominasi oleh kegiatan guru dengan metode ceramah dan pemberian tugas pada siswa, sedangkan kegiatan siswa lebih banyak diam dan mendengarkan penjelasan guru, sehingga keaktifan siswa pada saat proses pembelajaran kurang maksimal dan suasana kelas menjadi pasif.

Untuk ini, salah satu cara untuk mencapai keberhasilan dalam belajar fisika serta 
ISSN 23383240

mengatasi masalah yang menyebabkan siswa menjadi pasif adalah solusi alternatif memicu dalam menggunakan alat sederhana untuk mengganti alat-alat mahal dan sangat rumit yang tidak terdapat di sekolah tersebut.

Siswa akan menyenangi fisika jika memahami konsep fisika dan aplikasinya dalam kehidupan sehari-hari. Agar konsep fisika dapat dipahami dengan baik dan benar oleh siswa maka pengajaran fisika harus dititikberatkan pada peran siswa secara aktif.

Nyoman Kertiasa [3] dalam hasil penelitiannya mengatakan bahwa definisi media pengajaran sains sederhana atau biasa disebut media pengajaran sains buatan tangan, adalah alat yang dirancang dan dibuat oleh guru dengan menggunakan bahan yang tersedia di lingkungan. Dengan alat ini dapat membantu meningkatkan pemahaman konsep siswa antara kelas yang diberi model Problem Based Learning dengan kelas yang diberi model konvensional, dimana rata-rata nilai posttest yang diperoleh kelas eksperimen adalah 12,27 sedangkan rata-rata nilai posttest kelas kontrol adalah 7,00.

Berkenaan dengan hal-hal di atas, maka dipilih model Pembelajaran Berbasis Masalah sebagai model yang akan diterapkan. Model pembelajaran ini siswa tidak lagi belajar mengandalkan memori (ingatan) dengan mencontoh (misalnya, jawaban ujian sebelumnya) saja. Tujuan ini akan lebih maksimal apabila didukung oleh kemampuan menfasilitasi siswa. Materi konsep zat adalah materi yang sangat cocok jika diajarkan menggunakan model pembelajaran berbasis masalah dengan menggunakan alat sederhana. Hal ini disebabkan oleh beberapa faktor antara lain, materi ini sangat cocok disajikan dalam berbagai penggunaan alat-alat sederhana, karena konsep zat merupakan salah satu materi yang erat kaitannya dengan penemuanpenemuan konsep dan konsep zat banyak diaplikasikan dalam kehidupan sehari-hari contohnya perristiwa terjadinya penguapan dan masi banyak peristiwa-peristiwa lainnya. sehingga materi ini akan memudahkan siswa untuk mengidentifikasi dan menemukan pengetahuan.

MASALAH

Apakah terdapat perbedaan pemahaman konsep siswa kelas VII pada konsep zat antara kelas yang mendapatkan pembelajaran menggunakan Model Pembelajaran berbasis Masalah dengan kelas yang mendapatkan pembelajaran menggunakan model konvensional di SMP Negeri 1 Sindue Tobata?" TUJUAN
Untuk menguji signifikansi perbedaan pemahaman konsep siswa kelas VII pada konsep zat antara kelas yang mendapatkan pembelajaran menggunakan Model Pembelajaran Berbasis Masalah dengan kelas yang mendapatkan pembelajaran menggunakan model konvensional di SMP Negeri 1 Sindue Tobata.

\section{METODE PENELITIAN}

Penelitian ini menggunakan metode eksperimen kuasi, dimana desain penelitian yang digunakan adalah "The Non Equivalen Pretest-Posttest Desing" atau Rancangan Pratest-Pascates yang tidak Ekuivalen, yaitu menggunakan kelas-kelas yang sudah ada sebagai kelompoknya, dengan memilih kelaskelas yang sudah ada diperkirakan sama keadaan/kondisinya. Bentuk desainnya disajikan pada Tabel 1 berikut:

Tabel 1. Desain Penelitian

\begin{tabular}{|l|c|c|c|}
\hline \multicolumn{1}{|c|}{ Kelompok } & $\begin{array}{c}\text { Tes } \\
\text { Awal }\end{array}$ & $\begin{array}{c}\text { Variabel } \\
\text { terikat }\end{array}$ & $\begin{array}{c}\text { Tes } \\
\text { Akhir }\end{array}$ \\
\hline A(Eksperimen) & $\mathrm{O}_{1}$ & $\mathrm{X}_{1}$ & $\mathrm{O}_{2}$ \\
B (Kontrol) & $\mathrm{O}_{1}$ & $\mathrm{X}_{2}$ & $\mathrm{O}_{2}$ \\
\hline
\end{tabular}

Keterangan:

A : Kelompok eksperimen

B : Kelompok kontrol

$\mathrm{O}_{1}$ : Tes Awal

$\mathrm{O}_{2}$ : Tes Akhir

$X$ : Perlakuan dengan Pembelajaran Berbasis Masalah menggunakan laboratorium sederhana.

\section{HASIL DAN PEMBAHASAN}

Berdasarkan hasil validitas ahli, disetujui sebanyak 25 item soal yang diuji cobakan. Kedua puluh lima soal ini 20 nomor soal pilihan ganda dan 5 nomor soal esai sebelumnya telah dikoreksi dan disesuaikan dengan tujuan pembelajaran yang ingin dicapai. Soal-soal tersebut selanjutnya diuji cobakan pada siswa kelas VIII A. Berdasarkan hasil uji coba, selanjutnya dilakukan analisis berdasarkan validitas item, tingkat kesukaran dan daya pembeda sebagai berikut:

Uji Validitas Tes

Hasil uji validitas item tes berada pada kategori sangat rendah sampai dengan sedang. Adapun soal yang masuk dalam kategori sangat rendah dimana nilai koefisien korelasinya berada pada rentang $(0,06)-(0,19)$. Soal yang masuk dalam kategori rendah Dimana nilai koefisien $(0,21)-(0,38)$. Dan soal berada pada 
kategori sedang dengan nilai koefisien korelasi berada pada rentang $(0,23-0,51)$.

Indeks Kesukaran

Hasil analisis indeks kesukaran atau tingkat kesukaran soal berada pada kategori mudah sampai dengan sukar. Adapun soal yang masuk dalam kategori mudah dengan nilai indeks kesukaran sebesar 0,73 . Soal yang masuk dalam kategori sukar dimana nilai indeks kesukarannya sebesar 0,27. Dan soal yang masuk dalam kategori sedang, dengan nilai indeks kesukarannya berada pada rentang 0,31 $-0,65$.

Daya Pembeda

Hasil analisis daya pembeda, soal-soal tersebut berkategori jelek sampai dengan baik. Soal yang masuk dalam kategori jelek dengan nilai analisis daya pembedanya berada pada rentang $(-0,23)-(0,15)$. Soal yang masuk dalam kategori cukup dengan nilai analisis daya pembedanya berada pada rentang $(0,23)$ $(0,38)$. Sedangkan soal yang masuk dalam kategori baik dengan nilai analisis daya pembedanya berada pada rentang $(0,54)$ $(0,69)$.

Reliabilitas

Analisis berdasarkan reliabilitas tes. Suatu tes dikatakan reliabel jika $r_{11}>0,70$ dan nilai reliabilitas tes $\left(r_{11}\right)$ yang diperoleh dari hasil penelitian ini sebesar 0,80. Hal ini menunjukkan bahwa nilai reliabilitas tes hasil perhitungan lebih besar dibandingkan nilai reliabilitas tes yang ditentukan.

Hasil Pretest Pemahaman Konsep

Tabel 2. Deskripsi Skor Tes Pemahaman Konsep Fisika Kelas Eksperimen dan Kelas Kontrol (Pretest)

\begin{tabular}{|l|c|c|}
\hline \multicolumn{1}{|c|}{ Deskripsi } & $\begin{array}{c}\text { Kelas VII A } \\
\text { (Eksperimen) }\end{array}$ & $\begin{array}{c}\text { Kelas VII B } \\
\text { (Kontrol) }\end{array}$ \\
\hline Jumlah Siswa & 30 & 30 \\
\hline Skor Minimum & 2 & 2 \\
\hline Skor Maksimum & 12 & 11 \\
\hline Skor Total & 209 & 180 \\
\hline Skor Rata-rata & 6,57 & 6,00 \\
\hline Standar Deviasi & 2,31 & 2,35 \\
\hline
\end{tabular}

korelasinya berada pada rentang

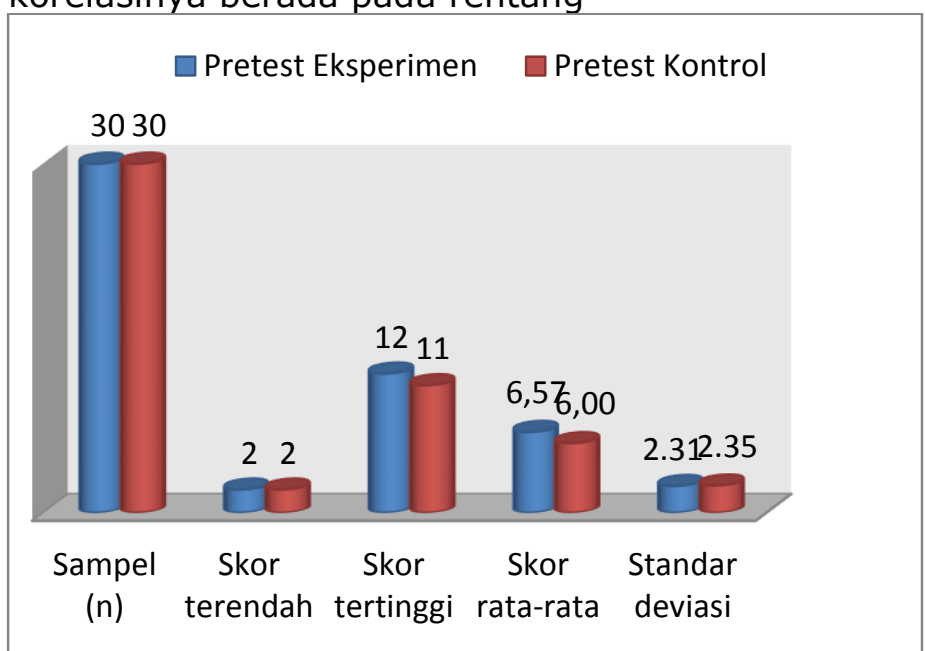

\section{Gambar 1. Skor Tes Pemahaman Konsep (Pretest)}

Uji Normalitas

Berdasarkan hasil uji normalitas diketahui nilai $X^{2}$ Hitung $<X^{2}$ tabel atau $X^{2}$ Hitung baik kelas eksperimen maupun kelas kontrol lebih kecil dibandingkan nilai $X^{2}$ tabel. Dimana untuk kelas eksperimen $7,43<7,81$ dan untuk kelas kontrol 6,31<7,81. Sesuai kriteria pengambilan keputusan, maka baik data dari kelas eksperimen maupun kelas kontrol keduanya berasal dari populasi yang terdistribusi normal.

Uji homogenitas

Berdasarkan hasil uji homogenitas diketahui nilai Fhitung lebih kecil dibandingkan dengan nilai $F_{\text {tabel. }}$. Dengan kata lain $F_{\text {hitung }}<\mathrm{F}_{\text {tabel }}$ atau $\mathrm{F}_{\mathrm{o}}<$ $\mathrm{F} \alpha\left(\mathrm{v} 1, \mathrm{v}_{2}\right)$, secara matematis dapat dituliskan $1,27<1,80$. Berdasarkan kriteria pengambilan keputusan, diketahui data tersebut memiliki varians yang sama atau homogen. Artinya, tidak terdapat perbedaan varians antara kelas eksperimen maupun kelas kontrol.

Uji Hipotesis (Uji-t) pretest

Berdasarkan nilai rata-rata pretest kelas eksperimen sebesar 6,57 dan kelas kontrol sebesar 6,00, dilakukan uji hipotesis (uji-t) beda rata-rata (dua pihak) dan diketahui nilai $t_{\text {thitung }}=1,03$. Selanjutnya untuk nilai tabel dimana tabel $=\mathrm{t}_{(1-1 / 2 \mathrm{a})}$ pada taraf nyata $\mathrm{a}=$ 0,05 dan $d k=\left(n_{1}+n_{2}-2\right)=30+30-2=$ 58 , diperoleh $t_{0,975(58)}=2,00$ dan kriteria pengujian dimana $\mathrm{H}_{\mathrm{o}}$ diterima jika $-\mathrm{t}_{(1-1 / 2 \alpha)}<\mathrm{t}$ $\left.<\mathrm{t}_{(1-1 / 2} \alpha\right)$, diketahui $-2,00<1,03<2,00$. Hal ini berarti, nilai thitung berada pada daerah penerimaan $\mathrm{H}_{\text {o. }}$. Dengan kata lain, bahwa tidak terdapat perbedaan pemahaman konsep antara kelas VII A dengan kelas VII B. 
Vol. 2 No. 2

ISSN 23383240

Hasil Posttest Pemahaman Konsep

Tabel 3. Deskripsi skor tes pemahaman konsep fisika kelas eksperimen dan kelas kontrol (posttest).

\begin{tabular}{|l|c|c|}
\hline \multicolumn{1}{|c|}{ Deskripsi } & $\begin{array}{c}\text { Kelas VII A } \\
\text { (Eksperimen } \\
\text { ) }\end{array}$ & $\begin{array}{c}\text { Kelas VII B } \\
\text { (Kontrol) }\end{array}$ \\
\hline Jumlah Siswa & 30 & 30 \\
\hline Skor Minimum & 5 & 3 \\
\hline Skor Maksimum & 15 & 12 \\
\hline Skor Total & 368 & 210 \\
\hline Skor Rata-rata & 12,27 & 7,00 \\
\hline Standar Deviasi & 3,60 & 3,04 \\
\hline
\end{tabular}

$\square$ Posttest Eksperimen $\quad \square$ Posttest Kontrol

3030

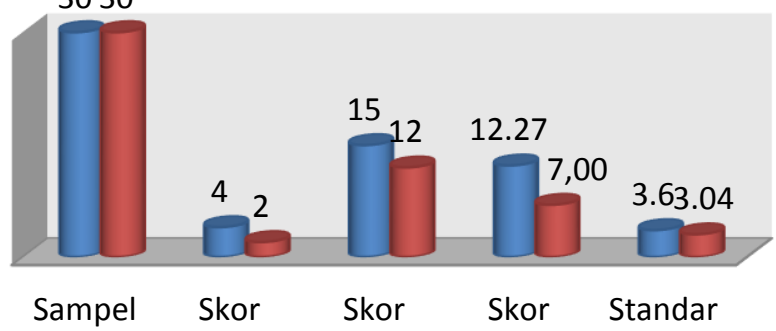

(n) terendah tertinggi rata-rata deviasi

\section{Gambar 2. Skor Tes Pemahaman Konsep}

\section{(Posttest)}

Uji hipotesis (uji-t) posttest

Berdasarkan nilai rata-rata posttest kelas eksperimen sebesar 12,27 dan kelas kontrol sebesar 7,00, dilakukan uji hipotesis (uji-t) beda rata-rata (dua pihak) dan diketahui nilai $t_{\text {hitung }}=12,5$. Selanjutnya untuk nilai tabel dimana tabel $=\mathrm{t}_{(1-1 / 2 \mathrm{a})}$ pada taraf nyata $\mathrm{a}=$ 0,05 dan $\mathrm{dk}=\left(\mathrm{n}_{1}+\mathrm{n}_{2}-2\right)=30+30-2=58$, diperoleh $t_{0,975(58)}=2,00$ diketahui thitung $\geq$ ttabel atau $12,5 \geq 2,00$. Hal ini berarti, nilai thitung berada di luar daerah penerimaan $\mathrm{H}_{0}$. Dengan demikian $\mathrm{H}_{0}$ ditolak dan $\mathrm{H}_{1}$ diterima, dan dapat disimpulkan bahwa terdapat perbedaan pemahaman konsep siswa antara kelas yang mendapatkan pembelajaran menggunakan model problem based learning dengan kelas yang mendapatkan pembelajaaran menggunakan model konvensional.

Berdasarkan hasil penelitian sebelumnya tentang penggunaan alat sederhana dengan hasil penelitian yang dilakukan bahwa pada penelitian sebelumnya, menurut Nyoman Kertiasa [3] yang menyatakan tentang pengerian alat peraga/praktik IPA sederhana atau disebut juga alat IPA buatan sendiri, adalah alat yang dapat dirancang dan dibuat sendiri Berdasarkan data yang diperoleh tersebut, kemudian dilakukan analisis dengan memanfaatkan alat/bahan di sekitar lingkungan kita, dalam waktu relatif singkat dan tidak memerlukan keterampilan khusus dalam penggunaan alat, dapat menjelaskan konsepkonsep atau gejala-gejala yang sedang dipelajari, alat lebih bersifat kualitatif daripada ketetapan kuantitatif. Ada dua aspek keuntungan yang bisa didapatkan dengan penggunaan alat praktek IPA sederhana yaitu dari sisi kinerja kualitatif cukup baik dan di lain sisi menimbulkan efesiensi biaya sehingga sekolah mampu mengirit dana operasional yang bisa digunakan untuk memenuhi kebutuhan lain.

Kualitas pembelajaran Sains SD pada daerah terpencil di Kabupaten Donggala telah dilakukan oleh Saehana [4] Hasil yang lebih baik melalui ujicoba lebih luas tentang alat sederhana, dimana rerata nilai tes adalah 4,63 dan 8,44 . Sedangkan rerata n-gain 70,99 yang berada dalam kategori tinggi. Uji model menunjukkan hasil belajar siswa yang mengikuti pembelajaran kooperatif dengan media alat sains sederhana lebih baik daripada siswa yang mengikuti pembelajaran kooperatif tanpa menggunakan media (Saehana, 2008).

Penelitian ini berbeda dengan penelitian menggunakan model Problem Based Learning yang telah dilakukan berdasarkan penelitian bahwa, kemampuan awal siswa dari pemberian tes awal (pretest) diperoleh skor rata-rata dari masing-masing kelas adalah 6,57 untuk kelas eksperimen dan 6,00 untuk kelas kontrol. Hasil ini menunjukkan adanya perbedaan skor antara kedua kelas, dimana terlihat skor untuk kelas eksperimen lebih tinggi dibandingkan kelas kontrol. Hasil ini berbeda dengan hasil pengujian hipotesis dengan menggunakan uji-t dua pihak. Berdasarkan hasil uji hipotesis dengan menggunakan taraf signifikansi $\mathrm{a}=$ 0,05 , diperoleh thitung $=1,03$ dan $\mathrm{t}$ tabel $=2,00$. Hasil ini menunjukkan $-\mathrm{t}_{(1-0,5 a)}<\mathrm{t}_{\text {hitung }}<\mathrm{t}_{(1-}$ $0,5 a)$ atau $-2,00<1,03<2,00$. Berdasarkan hasil tersebut diketahui, hipotesis $\mathrm{H}_{0}$ diterima.

Artinya, sebelum diberikan perlakuan berupa pemberian model pembelajaran problem based learning dengan menggunakan alat sederhana pada proses pembelajaran, tidak terdapat pengaruh pemahaman konsep antara kedua kelas. Hal ini yang kemudian menjadi salah satu alasan pendukung kedua kelas ini memenuhi syarat untuk dijadikan sampel. Selanjutnya, Untuk kemampuan siswa dari pemberian tes akhir (posttest) diperoleh nilai rata-rata dari masing-masing kelas adalah 12,27 untuk kelas eksperimen dan 7,00 untuk kelas kontrol.

Terhadap normalitas serta homogenitas varians. Hasilnya baik data pretes maupun 
ISSN 23383240

posttest keduanya berdistribusi normal dan memiliki varians yang homogen.

Berdasarkan analisis kuantitatif data posttest diketahui, nilai rata-rata kelas eksperimen lebih besar dibandingkan dengan nilai rata-rata kelas kontrol Perbedaan antara rerata skor posttest kelas eksperimen dan kelas kontrol menunjukkan adanya pengaruh model pembelajaran yang diterapkan pada kedua kelas tersebut. Pengaruh yang signifikan terjadi pada kelas eksperimen. Dimana kelas eksperimen menggunakan model problem based learning dalam penggunaan alat sederhana pada model pembelajarannya sedangkan kelas kontrol menggunakan model konvensional. Setelah dilakukan uji normalitas dan homogenitas varians, selanjutnya dilakukan uji hipotesis dengan menggunakan uji-t dua pihak berdasarkan hasil skor pretest dan skor posttest. Berdasarkan hasil skor pretest dimana kedua kelas belum diberikan perlakuan, diperoleh nilai thitung $=1,03$ dan nilai tabel $=2,00$. Dengan menggunakan kriteria penerimaan dimana $-t_{(1-0,5 a)}<t<t_{(1-0,5 a)}$ diketahui $\mathrm{H}_{0}$ diterima dan hipotesis satu $\left(\mathrm{H}_{1}\right)$ ditolak. Artinya sebelum diberikan perlakuan berupa pemberian model pada proses pembelajaran, tidak terdapat pengaruh pemahaman konsep antara kedua kelas baik kelas eksperimen maupun kelas kontrol.

Selanjutnya dengan menggunakan rata-rata skor posttest dimana pada masing-masing kelas telah diberi perlakuan, diperoleh nilai $t_{\text {hitung }}=12,5$ dan nilai tabel $=2,00$. Dengan menggunakan kriteria penerimaan $\mathrm{H}_{0}$ dimana -

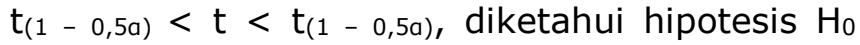
tidak terpenuhi atau ditolak dan hipotesis satu $\left(\mathrm{H}_{1}\right)$ diterima. Artinya terdapat pengaruh pemahaman konsep antara kelas yang mendapatkan pembelajaran menggunakan model problem based learning dalam penggunaan alat sederhana dengan kelas yang mendapatkan pembelajaaran menggunakan model konvensional.

Terjadinya pengaruh hasil tes pemahaman konsep terutama pada kelas eksperimen, dimungkinkan karena pada proses pembelajaran menggunakan model problem based learning dengan menggunakan alat sederhana menjadikan siswa lebih aktif dalam memecahkan masalah dan terlibat langsung dalam proses pembelajaran dimana informasi dan pengetahuan mereka temukan secara mandiri dalam kelompok, saling berinteraksi bukan hanya dengan guru tetapi juga dengan teman mereka, dengan model pembelajaran yang digunakan membuat siswa menjadi lebih kreatif dalam menyelesaikan masalah dan menerapkan ilmu fisika dalam kehidupan sehari-hari dengan memanfaatkan alat sederhana dilingkungan sekitarnya, sehingga pemahaman konsep dan kemampuan penemuan siswa secara individu maupun kelompok dapat meningkat.

Dari hasil penelitian ini dapat disimpulkan bahwa Uji model menunjukkan hasil belajar siswa yang mengikuti pembelajaran Problem Based Learning dengan menggunakan alat sederhana lebih baik daripada siswa yang mengikuti pembelajaran menggunakan model konvensional tanpa menggunakan alat sederhana.

\section{KESIMPULAN}

Berdasarkan penelitian dan analisis data dapat disimpulkan, bahwa hasil rata-rata kelas kontrol sebesar 7,00 dengan rata-rata kelas eksperimen sebesar 12,27. Berdasarkan penelitian kuantitatif bahwa hasil kelas eksperimen yang diberikan model pembelajaran Problem Based Learning lebih meningkat dibandingkan dengan kelas kontrol yang diberikan model pembelajaran konvensional di SMP Negeri 1 Sindue Tobata. Hal ini dapat dilihat dari hasil pengujian hipotesis dengan menggunakan uji-t dua pihak pada posttest, dimana dengan menggunakan rata-rata skor diperoleh nilai thitung $=12,5$ dan tabel 2,00. Berdasarkan data tersebut, kriteria penerimaan $\mathrm{H}_{\mathrm{o}}$ dimana $-\mathrm{t}_{(1-0,5 \alpha)}<\mathrm{t}<\mathrm{t}_{(1-0,5 \alpha)}$ tidak terpenuhi, $\mathrm{H}_{\mathrm{o}}$ ditolak dan hipotesis satu $\left(\mathrm{H}_{1}\right)$ diterima pada taraf nyata $5 \%$ dan $\mathrm{dk}=58$.

\section{DAFTAR RUJUKAN}

[1] Nurjannah, (2008). Pengaruh Pembelajaran Interaktif Berbasis Konsep Terhadap aktifitas dan Pemahaman Konsep Fisika Siswa Khususnya Materi Fisika Dalam Bahasan "Cahaya Optik (Geometri)". Skripsi pada Universitas Pendidikan Indonesia: Diterbitkan.

[2] Tan, O.S. (2004). Eanhancing Thingking hrough Problem Based Learning. Approaces. Singapore.

[3] Nyoman Kertiasa (1994). Pemanfaatan Alat Sederhana Sebagai Sumber Belajara, diunduh pada tanggal 14 Mei 2013.

[4] Saehana, (2008). Studi Pengembangan alat Sains Sederhana dari Barang-barang bekas Untuk meningkatkan Kualitas Pembelajaran Sains SD Pada Daerah Terpencil di Kabupaten donggala. 